\title{
Nigeria: \\ Power-Sharing and the Resurgence of Separatist Agitation. The Prospect of a Consociational Model
}

\author{
Olusola Samuel OYETUNDE
}

\begin{abstract}
The theory of consociationalism has been extensively discussed in literature; however, its feasibility in managing conflicts in deeply divided societies is heavily contested. The few studies that have examined how the theory applies in real-world situations remain inconclusive. The present work, therefore, explored the prospect of consociational power-sharing model in addressing the problem of under-representation, political exclusion, and marginalization in Nigeria. This is against the backdrop of the incessant separatist agitations in Nigeria, which has undermined the peace, stability, and unity of the country. Using qualitatively analyzed data from secondary sources, this study argues that even though Nigeria does not meet any of the favorable conditions of consociationalism set out by Lijphart (1985), it would still benefit from consociational power-sharing. The study proposes the adoption of semi-presidentialism based on the principle of grand coalition and proportionality and gives an assessment of how it could work for Nigeria. It contends that the rotation of power among the six geo-political zones in the country and the adoption of proportional sequential mechanism would facilitate elite cooperation and inclusion of all segments of the society in the political process, thereby easing the fear of sectional domination in Nigeria.
\end{abstract}

Keywords: power-sharing, consociationalism, separatist agitation, under-representation, political exclusion, Nigeria.

\section{Introduction}

In Nigeria, the quest for secession based on claims of political exclusion, marginalization, and perceived sense of injustice by various ethnic groups has been a reoccurring phenomenon since independence (Johnson, and Olaniyan, 2017). This clamour for greater autonomy led to the 1967-1970 Civil War fought between the Igbo ethnic group, who
Olusola Samuel OYETUNDE

School of Politics and International Relations, University of Kent, Canterbury, United Kingdom

E-mail: oyetundeolusolasamuel@gmail.com

Conflict Studies Quarterly

Issue 37, October 2021, pp. 54-74

DOI: $10.24193 / c s q .37 .4$

Published First Online: 05 October /2021 
wanted an independent Republic of Biafra, and the Nigerian government, who sought to maintain the status quo. Although the war ended in 1970, the underlying causes of the war have not been addressed. The inability to address the issues has led to the increasing marginalization of the Igbos in all spheres of the Nigerian polity (Harnischfeger, 2011). Consequently, the situation has resulted in the resurgence of the agitation for the Republic of Biafra by groups such as Movement for the Actualization of the Sovereign State of Biafra, Biafra Zionist Movement and more recently, the Indigenous People of Biafra (Abada et al., 2020). At the center of these separationist agitations, is the problem of power-sharing among various ethnic configurations that constitute the Nigerian society.

Arend Lijphart (1969) developed the concept of "consociationalism" as a power-sharing arrangement designed to resolve conflicts in plural societies through elite's cooperation and formalized power-sharing institutions, which could lead to democratic consolidation. The consociational model consists of empirical and normative elements (Orji, 2008). The empirical component elucidates democratic stability in culturally divided western countries such as the Netherlands, Switzerland, and Belgium. Arend Lijphart $(1969$, p. 212) argues that the stability in some European states is a consequence of the attempts by political elites to "counteract the immobilizing and unstabilizing effects of cultural fragmentations". The normative element, on the other hand, rests on the contention that the pattern of consociationalism observed in Europe might contribute to democratic stability if extended to other divided societies in the world (Orji, 2008). However, the attempts to extend the empirical aspect of consociationalism to the normative have been criticized by scholars who argue that the experience of countries such as Switzerland may not be suitable for other multi-segmental countries (Barry, 1975; Steiner, 1981).

In response to these criticisms, Lijphart (1985) identified nine conditions that make consociationalism favorable. They are (a) lack of an ethnic majority (b) lack of substantial social and economic differences (c) ethnic groups of nearly equivalent size (d) small number of groups (e) small demographic size (f) external threats (g) overarching loyalties (h) geographic concentration of groups and (i) previous conditions of compromise and accommodation (Lijphart, 1985). Furthermore, he states that the conditions are neither necessary nor sufficient for the effective implementation of consociationalism as all countries irrespective of their historical and political realities could benefit from the model (Lijphart, 1985). However, this position has been criticized by scholars who argue that Lijphart failed to take individual differences and specific needs of each society into consideration. For instance, none of the favorable conditions of consociationalism appears to be present in Nigeria (Njoku, 1999). Nevertheless, Lijphart (1969) contends that power-sharing is a solution for states emerging from ethnic, religious, social, or political conflicts, and thus insisted that the consociational model should be adapted or changed to fit the specific needs of each state (Rees, 2007). 
This article assesses how the consociational model would work in Nigeria, even though the country does not seem to fulfill any of the favorable conditions. It argues for the adoption of a semi-presidential system based on the principle of proportionality and grand coalition. The study contends that the adoption of consociationalism in Nigeria would lead to the incorporation of marginalized groups in decision-making processes, which would help to quell secessionist agitations. This article is structured into three parts. First is a discussion of the theoretical argument followed by an analysis of the political realities of Nigeria. The final section examines the prospect of adopting consociationalism in Nigeria.

\section{Theory}

Power-sharing has generated significant attention in the field of conflict management since the end of the Cold War because of the emergence of ethnic cleavages and pursuit of self-independence as one of the factors responsible for violent conflicts in the world. Several "third world" countries that have experienced violent conflicts since the end of the Second World War have succeeded in ending the conflict through the conclusion of peace agreements and formation of a unity government using power-sharing as a stabilizing mechanism (Adekanye, 1998). The concept of power-sharing has a broader scope that involves all forms of political arrangements which deal with power allocation such as political, military, economic and territory. Moti (2012) sees power-sharing as a mechanism for settling disputes regarding who should occupy the most influential position in a political system through the joint exercise of power, which is designed to enable unity and integration. It provides the majority and minority groups in the polity with the ability to represent and make decisions on common concerns including a level of autonomy over subjects relevant to the groups (Sisk, 1996). The adoption of an appropriate power-sharing arrangement is often seen as a political remedy for societies endangered by civil conflicts because it ensures that conflicting parties are accommodated and included in a joint coalition government (Binningsbo, 2013).

Arend Lijphart developed the theory of consociationalism as an approach for resolving conflict in deeply divided societies based on extensive studies of the power-sharing elements in Switzerland, Belgium, and the Netherlands. He argues that centrifugal forces in divided societies can be counterbalanced through the process of elite cooperation, which is based on collaborative policies among representatives of various groups in a political system (Lijphart, 1977). The advocates of consociational power-sharing contend that accommodating the interests of different fractions through a formal power-sharing arrangement would facilitate the achievement of post-conflict settlement in multi-ethnic societies (Bogaards, 2019). They further contend that the integration of the demands of different segments of the society into institution arrangements would help to curb the threats of secession and civil war through the guarantee of significant participation in politics (Mehler \& Degenhardt, 2008). Thus, O'Leary (2003) perceives consociation as 
a state where there is peaceful coexistence between at least two groups, which are not institutionally superior to each other and where there is political cooperation among significant communities through self and shared government.

Lijphart (2002) identifies grand coalition, proportional representation, segmental autonomy, and mutual veto as the four significant characteristics of consociationalism. Grand coalition deals with the involvement of all major groups in governance and the political process. McCulloch and McGarry (2009) argue that the grand coalition is a typical feature of a parliamentary system of government due to its association with the establishment of a multiparty cabinet. Though consociational executive can also be noticed in a presidential system, Lijphart (2007) preferred a parliamentary provision because of its collegiality and capacity to counteract majoritarianism. Furthermore, segregated autonomy refers to the minority rule over matters of exclusive concern intended to facilitate their inclusion into a broader institutional framework (McCulloch \& McGarry, 2009). This autonomy can take either a territorial form, non-territorial form, or a combination of the two (Njoku, 1999). Devolution and decentralization are examples of ways of granting autonomy on a territorial basis, while the non-territorial involves the freedom on social and cultural issues (McCulloch \& McGarry, 2009).

Reilly (2000) states that proportional representation enables the fair representation of ethnic minorities in politics, political appointments, and revenue allocation in proportion to their population. The proportional representation system is designed to safeguard the maximum representation of the citizen by ensuring that the parliament's composition reflects their electoral choice. Lijphart (1984) categorize proportional representation into List and Single Transferable Votes (STV). The STV is an electoral technique that utilizes multi-member constituencies and allows political parties to present multiple candidates, which are ranked by the electorates in order of preference (Banks, 2017). In STV, the electorates' vote can be transferred to other competing candidates if their first choice is eliminated or has more than the required votes. In contrast, the List allows the voters to elect their representatives from the list presented by the political parties and the seats won is in proportion to the parties' overall share of the popular votes received (Reynolds et al., 2008). The final element of Consociationalism is Mutual Veto, which enables the protection of minorities' interests by facilitating their inclusion in the decision-making process and prevents them from being outvoted by the majority. Mutual Vetoes can be informal, constitutional given or both (McCulloch and McGarry, 2009).

However, Brass (1991) argues that the consociational model is undemocratic because it can lead to the violation of right of individuals and groups and prevent political opposition; thus, making it a loser-takes-all system. It is also argued that even in a democratic setting, the application of the grand coalition principle is questionable because of interethnic competition (Åkerfeldt, 2016). Besides, Horowitz (1985) contends that 
consociationalism is a Eurocentric model built on the experience of the Europeans, which makes it unsuitable for multi-segmental societies of the 'third world'. Critics also claim that the regional autonomy associated with the consociational model could lead to increased conflict between various segments of the society, which might lead to secession and partition (Nordlinger, 1972; Bellamy, 2000). The attempts to address the weaknesses of the consociational model led to the development of the centripetal model, which is based on Horowitz's (1985) claim that consociationalism does not emphasize incentives for inter-group accommodation. McGarry and Loizides (2015) contend that centripetalism seeks to promote the influence of a minority on majority decision-making using electoral rules that make cross-ethnic appeals among political leaders necessary. Thus, centripetalism advocates for the coalition of elites before an election through vote pooling, which occurs when political elites seek external support from another group to emerge victorious in an election, and there is an exchange of votes by the electorates across group boundaries (Bogaards, 2019).

\section{Establishing Nigeria's Political Realities}

\section{- Socio-Political Background}

Nigeria is a complex conglomeration of cultural, ethnic, and religious diversities with over 250 ethnic nationalities (Orji, 2008). As of 17 April 2021, Nigeria's population was estimated to be about 206 million making up about 2.64 per cent of the world's population (Worldometer, 2020). The major ethnic groups, which exercise the most political influence are the Hausa/Fulani, Yoruba, and the Igbo, and they constitute about 29, 21, and 18 per cent of the total population respectively (CIA, 2015). The Hausa/Fulani are distributed across the northern part of the country, with a Muslim majority, while the Igbos, located in the Southeast, and are predominately Christians. However, there is a balance between Christianity and the Islamic population in the South-West, which is home to the Yoruba with a tiny proportion practicing African Traditional Religion (Rustad, 2008). This composition makes it difficult to detach ethnic, regional, and religious divides from Nigerian domestic politics. Due to its diversity, Nigeria has witnessed many intra-state and state-level conflicts such as the civil war in 1967, driven by the competition over the control of political power among the major ethnic groups (Falode, 2011).

To promote unity in diversity, Nigeria operates a federal system of government. As a federation of three governmental levels, political power is divided between the central government, thirty-six states and 774 local government areas including the Federal Capital Territory in Abuja (See Figure 1). Nigeria is further divided into six geo-political zones according to economic, ethnic, political, and cultural preferences for power-sharing and resource allocation purposes (Bakare, 2015). The six sub-regions, reflecting the North-South Divide are the North West, North East, North Central, South West, South 
East and South-South (See Figure 1). Nigeria practices a presidential system of government, where power is separated between the executive and legislature. The president is directly elected through universal adult suffrage. The National Assembly is made up of the Senate, and House of Representatives. The senate consists of 109 members with three members from each state and one from the Federal Capital Territory. In contrast, the House of Representatives comprise 360 members from the 360 constituencies in which the country is divided. The allocation of seats in the House of Representatives is based on the population and size of each state (Fashagba, 2019).

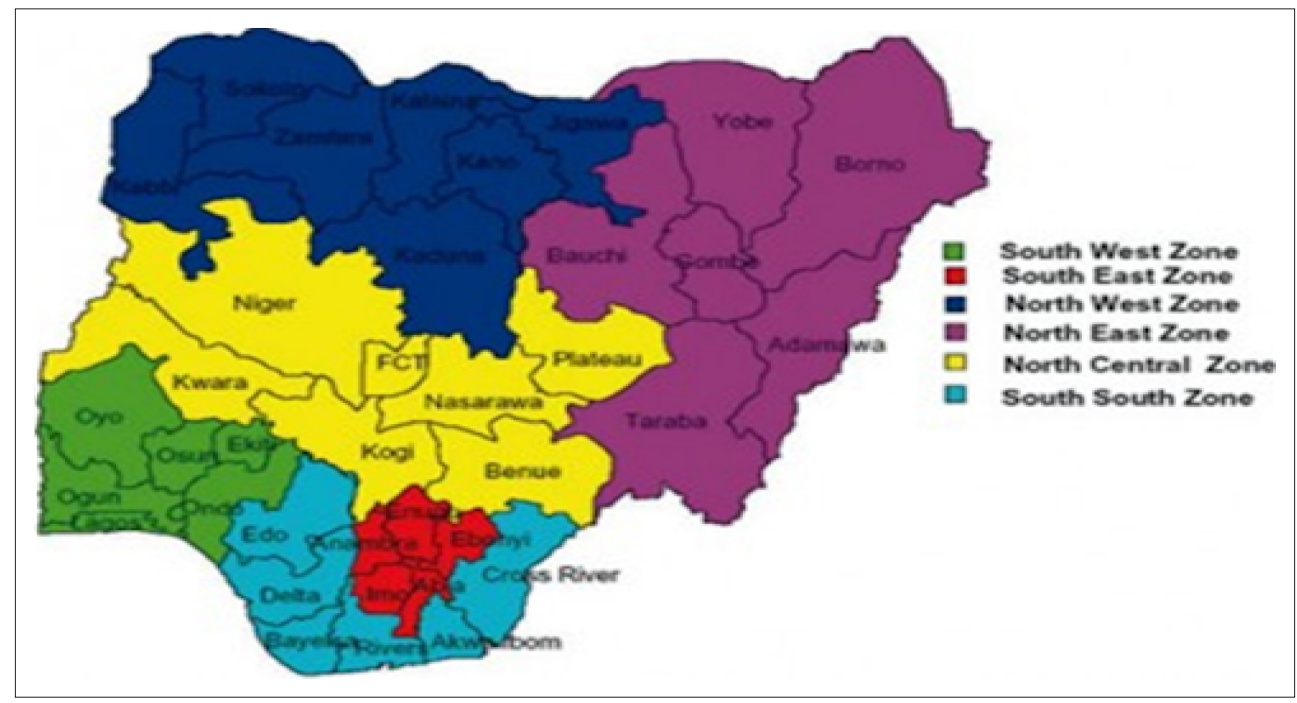

Figure 1: Map of Nigeria showing the Thirty-Six States and Geo-Political Zones

Source: Ibenegbu, (2017)

\section{- Issues and Challenges of Power-Sharing in Nigeria}

The power-sharing process in Nigeria aligns with some of the principles of consociationalism and centripetalism, especially in the division of power-sharing into territory, economics, and politics. Although the motive behind the institution of the three types of power-sharing is the same, this article focuses on the political aspect of power-sharing, which deals with office distribution. Central to the politics of political and bureaucratic office distribution is the need to prevent the domination of state institutions by a few groups (Orji, 2008). The two major ways of distributing elective or appointive positions in Nigeria are through zoning and federal character principles. The federal character principle is a constitutional provision, which authorizes equal representation of various groups in states institutions. On the other hand, the zoning principle is an informal arrangement developed by the political elites to ensure that each geo-political zone is adequately represented in government (Nwozor, 2014). The federal character principle 
and zoning seem to be a variant of the principle of consociationalism of elite coalition and proportional representation.

Federal Character was adopted as a framework for the promotion of equal representation and to prevent the dominance of individuals, few states or ethnic groups in government and its agencies. The principle was designed to address the problem of imbalance, marginalization, and discrimination in Nigeria public service. The Nigerian constitution mandates the president to appoint at least one minister from each state, and political appointments including civil service recruitments, are mandated to reflect the federal character (Demarest et al., 2020). As expected, the introduction of federal character led to an increase in the number of ethnic minorities in federal ministries and the spread of cabinet positions among various segments (Justine et al., 2015). However, the principle has failed to guarantee the equal allocation of public offices across the federating units in Nigeria due to a lack of political will as evident by the resurgence of the clamor for self-actualization by the Igbos (Eme \& Okeke, 2017). For instance, President Buhari's administration appears to have violated the provisions of the federal character principle in most of their political appointments by being ethnically biased in favor of the Northern region (see table 1). Furthermore, the federal character principle does not extend to elective positions, thereby, making it possible for the President, Senate President and Speaker of the House of Representatives to come from the same geo-political zone, which is against the idea of the principle of federal character (Okeke, 2019).

Table 1: Asymmetrical Appointments of Service Chiefs under President Buhari Administration

\begin{tabular}{|c|c|c|c|c|c|}
\hline S/N & Names & Position & Religion & State & Zone \\
\hline 1. & $\begin{array}{l}\text { Major General } \\
\text { Farouk Yahaya }\end{array}$ & Chief of Army Staff & Muslim & Sokoto & $\begin{array}{l}\text { North } \\
\text { West }\end{array}$ \\
\hline 2. & Yusuf Bichi & $\begin{array}{c}\text { Director-General } \\
\text { of the State Security Service }\end{array}$ & Muslim & Kano & $\begin{array}{l}\text { North } \\
\text { West }\end{array}$ \\
\hline 3. & $\begin{array}{l}\text { Air-Vice Marshal } \\
\text { Ishiaka Amao }\end{array}$ & Chief of Air Staff & Muslim & Osun & $\begin{array}{l}\text { South } \\
\text { West }\end{array}$ \\
\hline 4. & Rauf Adesoji Aregbesola & Minister of Interior & Muslim & Osun & $\begin{array}{l}\text { South } \\
\text { West }\end{array}$ \\
\hline 5. & $\begin{array}{l}\text { Retired Major General } \\
\text { Babagana Monguno }\end{array}$ & National Security Advisor & Muslim & Borno & $\begin{array}{c}\text { North } \\
\text { East }\end{array}$ \\
\hline 6. & $\begin{array}{l}\text { Major General } \\
\text { Bashir Magashi }\end{array}$ & Minister of Defence & Muslim & Sokoto & $\begin{array}{l}\text { North } \\
\text { West }\end{array}$ \\
\hline 7. & Usman Baba & Inspector-General of Police & Muslim & Yobe & $\begin{array}{c}\text { North } \\
\text { East }\end{array}$ \\
\hline 8. & Ahmed Abubakar & $\begin{array}{l}\text { Director-General, National } \\
\text { Intelligence Agency }\end{array}$ & Muslim & Katsina & $\begin{array}{l}\text { North } \\
\text { West }\end{array}$ \\
\hline
\end{tabular}




\begin{tabular}{|c|c|c|c|c|c|}
\hline S/N & Names & Position & Religion & State & Zone \\
\hline 9. & $\begin{array}{l}\text { Retired Colonel } \\
\text { Hameed Ali }\end{array}$ & $\begin{array}{c}\text { Comptroller-General } \\
\text { of Nigeria Custom Service }\end{array}$ & Muslim & Kaduna & $\begin{array}{l}\text { North } \\
\text { West }\end{array}$ \\
\hline 10. & Mohammed Babandede & $\begin{array}{c}\text { Comptroller-General of } \\
\text { Nigeria Immigration Service }\end{array}$ & Muslim & Jigawa & $\begin{array}{l}\text { North } \\
\text { West }\end{array}$ \\
\hline 11. & Haliru Nababa & $\begin{array}{c}\text { Comptroller-General of } \\
\text { Nigeria Correctional Service }\end{array}$ & Muslim & Sokoto & $\begin{array}{l}\text { North } \\
\text { West }\end{array}$ \\
\hline 12. & Boboye Oyeyemi & $\begin{array}{l}\text { Corps Marshall Federal } \\
\text { Road Service Corps }\end{array}$ & Christian & Kwara & $\begin{array}{l}\text { North } \\
\text { Central }\end{array}$ \\
\hline 13. & Dr Liman Ibrahim & $\begin{array}{l}\text { Comptroller-General } \\
\text { of Federal Fire Service }\end{array}$ & Muslim & Niger & $\begin{array}{l}\text { North } \\
\text { Central }\end{array}$ \\
\hline 14. & Ahmed Abubakar Audi & $\begin{array}{l}\text { Commandant-General of } \\
\text { the Nigeria Security and } \\
\text { Civil Defence Corps }\end{array}$ & Muslim & Nasarawa & $\begin{array}{l}\text { North } \\
\text { Central }\end{array}$ \\
\hline 15. & Abubakar Malami & $\begin{array}{l}\text { Attorney-General } \\
\text { of the Federation }\end{array}$ & Muslim & Kebbi & $\begin{array}{l}\text { North } \\
\text { West }\end{array}$ \\
\hline 16. & Abdulrasheed Bawa & $\begin{array}{l}\text { Executive Chairman of the } \\
\text { Economic and Financial } \\
\text { Crimes Commission }\end{array}$ & Muslim & Kebbi & $\begin{array}{l}\text { North } \\
\text { West }\end{array}$ \\
\hline 17. & $\begin{array}{l}\text { Retired General } \\
\text { Mohammed Buba-Marwa }\end{array}$ & $\begin{array}{c}\text { Chairman/Chief Executive } \\
\text { Officer } \\
\text { of The National Drug Law } \\
\text { Enforcement Agency }\end{array}$ & Muslim & Kaduna & $\begin{array}{l}\text { North } \\
\text { West }\end{array}$ \\
\hline 18. & $\begin{array}{l}\text { Major General } \\
\text { Lucky Irabor }\end{array}$ & $\begin{array}{c}\text { Chief } \\
\text { of Defence Staff }\end{array}$ & Christian & Delta & $\begin{array}{l}\text { South } \\
\text { South }\end{array}$ \\
\hline 19. & $\begin{array}{l}\text { Rear Admiral } \\
\text { Awwal Zubairu Gambo }\end{array}$ & $\begin{array}{c}\text { Chief } \\
\text { of Naval Staff }\end{array}$ & Muslim & Kano & $\begin{array}{l}\text { North } \\
\text { West }\end{array}$ \\
\hline 20. & Muhammed Dingyadi & $\begin{array}{c}\text { Minister } \\
\text { of Police Affairs }\end{array}$ & Muslim & Sokoto & $\begin{array}{l}\text { North } \\
\text { West }\end{array}$ \\
\hline
\end{tabular}

Source: Chiamogu and Chiamogu, 2019 (adapted and updated)

The second technique of office distribution in Nigeria is the Zoning principle. Ezeibe et al. (2016) define zoning of public office as the distribution and rotation of public office among various segments, which could be based on regions, ethnicity, or religion. The main elements of zoning mechanism in Nigeria are Power Shift and Rotation of Office. The zoning principle aims to ensure the inclusion of all regions in power and to ensure that no political party is perceived to represent only a particular segment of the country. For example, the presidential and vice-presidential candidates of various political parties are taken from different regions in Nigeria (Falola, 2008). The same principle applies in the selection of the leaders at the National Assembly. However, the power rotation principle has not been enshrined in the constitution, and the attempts to constitutionalize it have proven abortive, making it a subject of manipulation and controversies. Banjo (2010) argues that rotation of power is inconsistent with demo- 
cratic ideals because it allows political parties to allocate power based on loosely defined geo-political regions that are not authorized by the voters. The rotation arrangement has generated much discontentment under President Buhari administration by people who felt that it was unfair to have the Vice President and the Speaker of the House of Representatives from the South-West, and the President, Senate President and Chief Justice of Nigeria from the Islamic religion. This discontent partly demonstrates the reason for the resurgence of separatist agitation by groups who felt excluded and discriminated against in the political process.

The reason for the adoption of the federal character principle and the informal practice of the zoning principle is to balance the obvious inequality inherent in Nigeria's practice of liberal democracy principle of majoritarianism. However, Ukiwo, (2003) argues that the politicization of the principle of consociationalism in Nigeria has affected its effectiveness in checking conflict and competition based on ethnicity. Glickman and Furia (1995), thus submit that consociationalism is ineffectual in a presidential system characterized by the winner takes all approach as practiced in Nigeria. Hence, none of the power-sharing measures has ensured ethnic balance and equal representation in Nigeria's political process. Instead, these power-sharing arrangements have led to the reinforcement of separatist agitations by groups, who felt marginalized and underrepresented in government.

\section{- The Resurgence of Separatist Agitation in Nigeria}

The threat of separation by some ethnic groups in Nigeria is not a modern phenomenon. However, the contemporary dimension of these agitations is connected to the yet to be resolved national questions revolving around religion, ethnic balancing, marginalization, revenue allocation, power-sharing, among others (Awofeso, 2017). The current demand for an independent state of Biafra by some groups in South-East Nigeria can be traced to the Civil War, which was fought from 1967 to 1970. However, the new wave of separatist agitation started in 1999 with the advent of the Movement for the Actualization of the State of Biafra, who used peaceful approaches such as protest and display of Biafra symbols as tactics to further their objectives.

The emergence of the Indigenous People of Biafra (IPOB), who occasionally used violent means to further their objectives, has taken the agitation to a new dimension. The advent of IPOB is connected to the exclusion and marginalization of the Igbos in vital political positions, a situation that became worse under the President Buhari administration (Alumona et al., 2017). For instance, the Igbos are yet to produce a Nigerian president since the 1960s when Nnamdi Azikwe was a ceremonial president, and Aguiyi Irosi was the Military Head of State (see table 2). The attempts of the government to repress these agitations through violent means instead of addressing the underlying causes through dialogue has further intensified the demand. The resultant effect was 
clashes between the IPOB and state security apparatus, which eventually led to their proscription by the Nigerian government in 2017 (Ejeh et al., 2020).

Table 2: Nigeria's Previous and Current Presidents/Head of States and Government

\begin{tabular}{|c|c|c|c|c|}
\hline $\mathrm{S} / \mathrm{N}$ & Name & Position & $\begin{array}{c}\text { Geo-Political } \\
\text { Zone } \\
\end{array}$ & Tenure Period \\
\hline 1. & Nnamdi Azikwe & Ceremonial President & South East & 1960-1996 \\
\hline 2. & Tafawa Balewa & Prime Minister & North East & 1960-1966 \\
\hline 3. & $\begin{array}{l}\text { Major General } \\
\text { Aguiyi Ironsi }\end{array}$ & Military Head of State & South East & $\begin{array}{l}\text { January 16- } \\
\text { July 29, } 1966\end{array}$ \\
\hline 4. & $\begin{array}{l}\text { General } \\
\text { Yakubu Gowon }\end{array}$ & Military Head of State & North West & $\begin{array}{l}\text { July } 29,1966- \\
\text { July } 29,1975\end{array}$ \\
\hline 5. & $\begin{array}{l}\text { General } \\
\text { Murtala Mohammed }\end{array}$ & Military Head of State & North West & 1975-1976 \\
\hline 6. & $\begin{array}{l}\text { General } \\
\text { Olusegun Obasanjo }\end{array}$ & Military Head of State & South West & 1976-1979 \\
\hline 7. & Shehu Shagari & Executive President & North West & 1979-1983 \\
\hline 8. & $\begin{array}{l}\text { Major General } \\
\text { Muhammadu Buhari }\end{array}$ & Military Head of State & North West & 1983-1985 \\
\hline 9. & $\begin{array}{l}\text { General } \\
\text { Ibrahim Babangida }\end{array}$ & Military President & North Central & 1985-1993 \\
\hline 10. & Ernest Shonekan & $\begin{array}{l}\text { Head of State (Interim } \\
\text { National Government) }\end{array}$ & South-West & $\begin{array}{c}\text { August 26- } \\
\text { November 17, } 1993\end{array}$ \\
\hline 11. & $\begin{array}{l}\text { General } \\
\text { Sani Abacha }\end{array}$ & Military Head of State & North West & 1993-1998 \\
\hline 12. & $\begin{array}{l}\text { General } \\
\text { Abdulsalami Abubakar }\end{array}$ & Military Head of State & North Central & 1998-1999 \\
\hline 13. & Olusegun Obasanjo & Executive President & South West & 1999-2007 \\
\hline 14. & Musa Yaradua & Executive President & North West & $2007-2010$ \\
\hline 15. & Goodluck Jonathan & Executive President & South South & 2010-2015 \\
\hline 16. & Muhammadu Buhari & Executive President & North West & 2015 till date \\
\hline
\end{tabular}

Source: Alumona, Azam, and Iloh, 2017

Table 2 above indicates that the three geo-political zones from North (North East, North West and North Central) have occupied the position of the president more than other geo-political zones from the South (South East, South West, and South-South) throughout the country's sixty years of independence. The clamor for increased representation of the South-eastern zone in the political process is a major factor responsible for the resurgence of the separatist movements. However, since power-sharing is at the root of the various agitations, there is a need for the institutionalization of an effective power-sharing arrangement based on the consociational model to reduce inter-ethnic suspicion and enhance the involvement of all ethnic groups in the political process. 


\section{Consociational Power Sharing}

\section{as a Panacea to Secessionist Agitations in Nigeria}

\section{- Nigeria and Lijphart's Favorable Factors}

Nigeria could be considered as an unusual case because of the absence the favorable factors of consociationalism identified by Lijphart (1985). Schneckener (2002) contends that the chance of attaining a power-sharing agreement is greater where the favorable conditions are feasible than where they are non-existent. The following factors appear to be an impediment to the practice of consociationalism in Nigeria: (a) The dominant size of the Hausa/Fulani ethnic group compared to others groups (b) existing wide gap between the North and South in terms of socio-economic development (c) the existence of wide group inequalities in terms of size and economic resources (d) The non-existence of external threats that can prompt national solidarity (e) Huge population size (f) Absence of an overarching loyalty to the Nigerian nation (g) Lack of geographically concentrated ethnic groups (h) Absence of compromising and accommodative history (Njoku, 1999). The absence of these conditions in the Nigerian society is partly caused by colonialism, which created an artificial boundary and forcefully integrated people of diverse cultures and traditions (Nwonwu, and Kotze, 2008). Consequently, the amalgamation of different communities under one umbrella, called Nigeria led to an ethnic-based voting behavior, which further hinders consociational practice.

Notwithstanding, Fitri and Rahman (2015) argue that cooperation, accommodation, and compromise are still possible due to the absence of a clear majority between the three major ethnic groups in Nigeria. The lack of a clear dominant group enhances the possibility of the effectiveness of the consociational model in Nigeria because none of the three major ethnic groups is too large in terms of population size to dominate one another. However, Lijphart (1977) states that the possession of these conditions is not adequate or does not have to be present before consociationalism can be adopted or effective in any nation. Bogaards et al. (2010) state that the absence of favorable factors is not an insurmountable obstacle provided there is adequate political will from the elite. There is a possibility of success even when most of the conditions or the most decisive ones are unfavorable or absent. Therefore, the synthesis of consociational mechanisms is essential for the development of a recognized democratic system in Nigeria (Joseph, 1978).

\section{- Prospect of a Consociational Model in Nigeria}

The constitutional arrangement of any nation must address its historical and ethnological realities. Nigeria's attempts to build its democracy on the British parliamentary and the United States presidential model have not been effective due to its ethnoreligious composition and social-political environment, which is different from that of the Western countries (Akinola, 1996). Unlike the United Kingdom, there is an absence of 
an institution equivalent to the British monarch to function as a uniting force in the heterogeneous Nigerian society. Thus, when the parliamentary system was introduced at independence, the political parties were ethnically based and merely represented the various ethnic segments, which makes their relationship hostile towards one another, leading to various ethno-political conflicts and secessionist agitations. Similarly, the zero-sum nature of Nigeria's practice of the presidential system has failed to integrate the diverse population of the country by exacerbating the politics of ethnic anxiety leading to disintegrative conflicts (Suberu and Diamond, 2002). Therefore, due to the failure of these models, there is a need to either jettison or modify the current presidential system, revert to the parliamentary system, or adopt a new system of government that is more suited to the realities of Nigeria in order to accommodate and integrate the minorities by involving them in the decision-making process.

To resolve the issues surrounding power-sharing in Nigeria, this article proposes the adoption of a semi-presidential system adapted to suit its socio-political realities. Semipresidentialism integrates the features of the Parliamentary and Presidential systems of government by having a president who is directly elected for a fixed term and a prime minister plus the cabinet who are either responsible to the president or parliament (Elgie, 2008). Moestrup (2007) argues that having a dual executive permits a level of power-sharing between contending forces in the political system, thus enabling grand coalition and majority representation. In Nigeria, for instance, the adoption of a semi-presidential system would create the possibility for power to be shared between/ among various ethnic and sectional groups in the country. If the Northern region holds the presidency and the Southern region holds the prime ministership, the likelihood of integration would be higher because each region would have an institutional stake in the political process.

Lijphart (2004) agrees with the contention that semi presidentialism will enable substantial power-sharing among the executives in a political system. However, he argues that the system will not stop the zero-sum approach associated with pure presidentialism, which consolidates the power of the president. In order to prevent the over-concentration of power in the hands of the president, the French system of premier-presidentialism, in which the prime minister and his cabinets are answerable to the legislature, would be appropriate for a country such as Nigeria instead of the president-parliamentarism, where the prime minister and the cabinets are responsible to the president. This will help to deconcentrate and reduce the amount of power being wielded by the president (Choudhry and Stacey, 2013). The adoption of the premier-presidentialism in Nigeria would allow for a collective and unified government, where power is divided among the organs of government, thus serving as an effective strategy for inter-ethnic cohesion. France for instance, struggled with a parliamentary system in their Fourth Republic (1946-1958) when they had twenty governments in ten 
years but the adoption of a premier-presidentialism type of semi-presidential system in the Fifth Republic has ensured some degree of stability due to the stable, collective, and cohesive leadership (Skach, 2011).

The capacity of semi-presidentialism to generate intra-executive conflict between the president and prime minister, especially during the cohabitation period, which could lead to a divided executive and delay in decision-making has a subject of criticism (Elgie, 2008). However, Choudhry and Stacey (2013) state that it is possible to avoid such conflict if there is a well-structured relationship between the two executive and their powers clearly stated. An appropriate power distribution and structural relationships between the institutions of government would have a major impact on the success of semi-presidential systems. A premier-presidential Nigeria would benefit from the clear statement of the power and responsibilities of the president and prime minister and ensure that neither of them can exercise exclusive executive power. This would help to mitigate against any potential conflict that may arise in the performance of their duties.

In terms of power-sharing, the present six geo-political zones (see figure 1) are to function as the basis of allocating political power in Nigeria. Following the consociation model, the power rotation principle should be introduced and entrenched in the Nigerian constitution. This principle would rectify the shortfalls of the federal character principle by ensuring that all major groups in Nigeria occupy political power successively, thereby help to create a sense of belonging. The constitution should be amended to provide for the establishment of the office of the prime minister, deputy prime minister, President, and vice president at the executive level and senate president and speaker of the House of Representatives at the legislative level in accordance with the semi-presidential system. These positions should be rotated among the six geo-political zones in the country, and no zone should produce more than one occupant. Therefore, if the president is elected from a particular zone, the prime minister, senate president, deputy prime minister, speaker and vice president must be chosen from other zones to ensure balanced representation of different groups in governance. A major advantage of using the zones as the basis of power rotation is that it will reduce the impact of ethnicity and religion in the electoral process, thus lessening ethnoreligious conflict and separatist agitations (Ezeibe et al., 2016). Furthermore, inter-ethnic political rivalry and competition will be reduced because each zone will be aware of their turn to occupy certain political office thereby, minimizing the controversies surrounding which geo-political zones to present candidates when the opportunity arises. Thus, encouraging each zone to wait for their turn patiently.

Nwozor (2014) states that the focus on geopolitical power rotation is capable of depriving various ethnonational groups in Nigeria of their identities if not properly implemented. However, the power rotation principle has the potential of facilitating cordial relationships among various sections in Nigeria and promoting peace and stability in 
the country because it will ensure that marginalized groups are accommodated in the political and decision-making process. Power rotation will resolve the issue of national disunity and disintegration by recognizing the rights of all individuals irrespective of their ethnic and religious groups to be involved in the process of governance. Moreover, the proposed system would allow the office of the president, vice president, prime minister, and deputy prime minister to be distributed among the major religions in the country in order to maintain a religious balance. For instance, if the president is a Christian, the vice president is expected to be of the opposite religion. This will ensure that all sections of the society are given an equal status in the federation through adequate involvement in the power-sharing process.

Furthermore, when electing the president, the centripetal based electoral system currently being used where the winning candidate must obtain a minimum of one-quarter of votes cast in at least two-thirds of the thirty-six states of the Nigerian federation should be maintained. This arrangement will allow political parties to have a wide-ranging geographical and ethnic membership spanning two-thirds of the constituent states of the federation and ensure that no sectional group dominate governance since the president would enjoy widespread support. Bogaards (2019) contends that the theory of consociationalism and centripetalism are not necessarily mutually exclusive, and there is a possibility for the elements of both theories to be operated within a country. The presence of both features will better suit Nigeria's political realities because it will stop the accusations of parochialism or regionalism by groups who felt marginalized. Furthermore, the term of office of the president and vice president should be restricted to a single term of five years. If there is any vacancy due to impeachment, resignation, incapacitation or death, the vice president will temporally hold the office before the election of a new candidate from the same geo-political zone as the exited president to complete the tenure. This provision will help to eliminate succession controversies, prevent acrimonious power struggle between different zones and ensure the maintenance of the five-year power rotation among the zones.

The power rotation principle, along with the presence of a dual executive associated with a semi-presidential system is a manifestation of the consociational principle of elite cooperation and grand coalition. Grand coalition facilitates the involvement of all representatives of various factions in the political process. Lijphart (1984) states that peace and stability can be achieved in heterogeneous societies if political elites engage in accommodative behavior and abandon centrifugal competition among themselves. The constitutionalizing of the proposed system of government and power-sharing arrangements in Nigeria will promote stability by ensuring that the country's diversity is reflected in the composition of political elites through the facilitation of adequate representation of various groups. The rotation of executive and legislative power among geo-political zones will ensure that within the period of twenty-five to thirty years, each zone would have occupied all available principal positions. 
The concept of power rotation is not a new phenomenon. The European Union and Switzerland are prominent examples of countries and institutions that have effectively applied the principle of power rotation to suit their geo-political realities. The EU, for example, rotates its chairmanship position every six months among member states to give members equal access to council presidency regardless of their economic and political power or demographic size (Pasarín, 2011). In Switzerland, the German ethnic group who constitute the majority subscribes to the rotational principle in order to accommodate the minorities despite being capable of political dominance. This informal power-sharing arrangement in Switzerland provides for annual power rotation among federal councilors who take turns serving as president hierarchically starting from the most senior to the youngest member (Altman, 2008). Thus, making Switzerland one of the most stable multi-ethnic countries in the world.

Moreover, the consociational principle of proportional representation (PR) should be introduced in Nigeria to enhance the opportunities of participation for ethnic minorities in the legislature and executive arm of government. According to McGarry and Loizides (2015), the principle of proportionality allows a liberal model of consociation in which political parties are assigned positions if they meet the electoral threshold, irrespective of their basis. It will ensure that all candidates are rewarded as the winners and losers in the election would participate in decision-making or guarantee inclusion in government regardless of the total number of votes cast in their favor. Given the semi-presidential arrangement being proposed for Nigeria, PR should be introduced in the election at the legislative level and in the selection of cabinet ministers. At the legislative level, the PR electoral system should replace the problematic first-past-the-post winner system, where the party with the highest votes wins all legislative seats. This principle has the advantage of ensuring that all electorates are of equal value as all valid votes cast are considered, and no vote is rendered useless or wasted (Bakare et al., 2018). For instance, if a party has the support of twenty-five per cent voters, it will win about twenty-five per cent of legislative seats. This will help to guarantee inclusiveness of the minorities by giving them a stake in decision-making irrespective of their population because all political parties will be represented in the legislature regardless of the extent of their support base.

The "proportional sequential" mechanism, an innovative form of consociationalism proposed by McGarry and Loizides (2015) would be appropriate in the selection of ministers at the executive level in Nigeria. They argue that PS coalition would provide an inclusive and negotiable resolution to conflicts in heterogeneous political systems because positions are apportioned automatically on a proportional and liberal basis among the major political parties based on their electoral strength (McGarry \& Loizides, 2015). Thus, ministerial seats would be allotted in a way that is proportionate to the share of votes garnered by parties in the legislative election. The d'Hondt method 
currently being operated in Northern Ireland can be used as a divisor in the allocation of ministerial seats. The political party with the highest seats wins the first ministry, and each subsequent seat is allocated to the party with the highest votes after being divided by the divisor until all ministerial positions are occupied. Loizides (2016) states that the d'Hondt formula has the potential of facilitating the introduction of semi-presidentialism in resolving future deadlocks. Applying the PS executive coalition to Nigeria, the ministers would be drawn from political parties who have at least ten per cent of votes cast at the legislative election based on the d'Hondt method. The justification for setting the ten per cent votes limit is to ensure that political parties that get seats allocation in the National Assembly are parties who show dedication to galvanizing support base in the polity. This system will consolidate democracy by giving the minor political parties guaranteed seats in relation to the total votes received.

Another advantage of the P. S. coalition is that it will lead to the promotion of consensus-building instead of hostility among political parties, thereby reducing electoral violence as the winning party will integrate the losing party by giving them a certain percentage of legislative and executive positions. Violent competition, secessionist agitations and the possibility for losers to upset the whole framework will be reduced when all parties are included in the system. As the case of Northern Ireland suggest, the method will provide an incentive for political parties to stay away from violence and focus exclusively on politics to broaden their electoral support (Medina and Loizides, 2013). It will lead to the disbandment of the winner takes all approach that characterized Nigeria politics where the president appoints the ministers among the party loyalties. Finally, McGarry and Loizides (2015) state that the automaticity of the PS coalition makes it more beneficial because the formation of the executive ensues automatically after elections making further power sharing negotiation or legislative approval irrelevant. Thus, the bottleneck associated with seeking legislative approval in Nigeria will be eliminated if adopted.

\section{Conclusion}

The unity and continued existence of Nigeria are constantly being threatened by the increasing separatist agitations from ethnic minorities who use it as tool to express their dissatisfaction with the Nigerian state over their under-representation in the political process. The resurgence of separatist agitation by the Indigenous People of Biafra is based on the claims of marginalization, political exclusion, and underrepresentation being suffered by the Southeast geopolitical zones under the current political dispensation. This article argues that Nigeria could still benefit from implementing a consociational model of power sharing despite the absence of the favourable factors. To facilitate the inclusion of the diverse segments of the Nigerian society, it proposes the adoption of a semi-presidential system of government adapted to the political realities 
of the country based on the principle of grand coalition and proportional representation. It contends that the constitutionalizing of power rotation principle will discourage inter-ethnic rivalry and ethnoreligious conflict through facilitating cordial relationship among various groups in Nigeria. The rotation of power will lead to the accommodation of minorities in the decision-making process.

Furthermore, this article suggests that the principle of proportionality will enhance the opportunities available for minorities to participate in governance irrespective of their electoral strength. The study advocates for the adoption of the P. S. coalition based on the d'Hondt mechanism in the election of legislative members and executive ministers in Nigeria. This method will resolve the problem of underrepresentation and provide an incentive for political parties to stay away from violence and focus exclusively on politics to broaden their electoral support.

\section{References}

1. Abada, I. M., Omeh, P. H., \& Okoye, I. R. (2020). Separatist agitation by the indigenous people of Biafra (IPOB), and national question in Nigeria. Journal of Political Science, 2(1), 009-017.

2. Adekanye, J. B. (1998). Power-sharing in multi-ethnic political systems. Security Dialogue, 29(1), 25-36.

3. Åkerfeldt, A. (2016). Consociational democracy in theory and practice: A comparative case study of Rwanda and Burundi on power-sharing in state-building peaceagreements. Student Thesis, Dalarna University.

4. Akinola, A. A. (1996). The concept of a rotational presidency in Nigeria. The Round Table, 85(337), 13-24.

5. Altman, D. (2008). Collegiate executives and direct democracy in Switzerland and Uruguay: similar institutions, opposite political goals, distinct results. Swiss Political Science Review, 14(3), 483-520.

6. Alumona, I. M., Azam, S. N., \& Iloh, E. C. (2017). The Nigerian state and the resurgence of separatist agitations: The case of Biafra. African Heritage Institution.

7. Awofeso, 0. (2017). Secessionist movements and the national question in Nigeria: A revisit to the quest for political restructuring. IJRDO-Journal of Social Science and Humanities Research, 2(7), 25-55.

8. Bakare, M. O. (2015). Demography and medical education among Nigerian final year medical students-Implication for regional and human resource development. Journal of Health Education Research \& Development, 3(3), 1-5.

9. Bakare, A. R., Hassan, A. K., \& Aliu, F. O. (2018) Rethinking Nigerian electoral system for democratic sustainability: Can proportional representation lessen electoral tensions? Journal of Sustainable Development in Africa, 20(1), 245-260.

10. Banjo, L. (2010). Zoning of elective offices is destructive and fosters disunity. Retrieved from http://nigeriaworld.com/feature/publication/ banjo/031510.html. 
11. Banks, C. (2017). Single transferable vote and the need for electoral reform in the UK: Is the system too complex? King's Student Journal for Politics, Philosophy and Law, 1, 174-198.

12. Barry, B. (1975). Political accommodation and consociational democracy. British Journal of Political Science, 5(4), 477-505.

13. Bellamy, R. (2000). Dealing with difference: Four models of pluralist politics. Parliamentary Affairs, 53, 198-217.

14. Binningsbø, H. M. (2013). Power sharing, peace and democracy: Any obvious relationships?. International Area Studies Review, 16(1), 89-112.

15. Bogaards, M. (2019). Consociationalism and Centripetalism: Friends or Foes?. Swiss Political Science Review, 25(4), 519-537.

16. Bogaards, M., Basedau, M., \& Hartmann, C. (2010). Ethnic party bans in Africa: an introduction. Democratization, 17(4), 599-617.

17. Brass, P. R. (1991). Ethnic conflict in multiethnic societies: The consociational solution and its critics. In. P. R. Brass (Ed.), Ethnicity and Nationalism: Theory and Comparison (pp. 333-348). Sage.

18. Chiamogu, P. A., \& Chiamogu, U. P. (2019, 12-14 July). Ethnic and nepotic issues in Nigeria: Exploring the bane to public sector performance in the fourth republic. A paper presented at the International Conference on Social Sciences in the 21st Century, Amsterdam.

19. Choudhry, S., \& Stacey, R. (2013). Semi-presidentialism as a form of government: Lessons for Tunisia. Consolidating the Arab Spring-Constitutional Transition in Egypt and Tunisia. International IDEA \& The Center for Constitutional Transitions at NYU Law.

20. CIA. (2015). The World Factbook - Nigeria. Retrieved April 27, 2020 from https:// www.cia.gov/library/publications/the-world-factbook/geos/ni.html.

21. Demarest, L., Langer, A., \& Ukiwo, U. (2020). Nigeria's Federal Character Commission (FCC): A critical appraisal. Oxford Development Studies, 48(4), 315-328.

22. Ejeh, E. U., Bappah, A. I., \& Dankofa, Y. (2020). Proscription of terrorism in Nigeria: A comparative legal study. Commonwealth Law Bulletin, 46(3), 367-390.

23. Elgie, R. (2008). The perils of semi-presidentialism. Are they exaggerated? Democratization, 15(1), 49-66.

24. Eme, O. I., \& Okeke, M. I. (2017). Buhari presidency and federal character in Nigeria: A Human Needs Theory perspective. International Journal of Philosophy and SocialPsychological Sciences, 3(1), 74-90.

25. Ezeibe, C., Abada, I., \& Okeke, M. (2016). Zoning of public offices, liberal democracy and economic development in Nigeria. Mediterranean Journal of Social Sciences, 7(3), 328.

26. Falode, A. J. (2011). The Nigerian civil war, 1967-1970: A revolution?. African Journal of Political Science and International Relations, 5(3), 120-124.

27. Falola, T. (2008). Nigeria's stumbling democracy and its implications for Africa's democratic movement. ABC-CLIO. 
28. Fashagba, J. Y. (2019). Exploring the Nigerian Central Legislative Institution. In J. Fashagba, R. Ajayi and C. Nwankwor (Eds.), The Nigerian National Assembly (pp. 1-32), Springer.

29. Fitri, N. H. S. D. M., \& Rahman, B. A. (2015) Examining Ligphart's Favorable Conditions for Consociational Democracy in Nigeria. Public Policy and Administration Research, 5(11), 145-152.

30. Glickman, H., \& Furia, P. (1995). Issues in the analysis of ethnic conflict and democratization processes in Africa today. In H. Glickman (Ed.), Ethnic conflict and democratization in Africa (pp. 1-32). African Studies Association Press.

31. Harnischfeger, J. (2011). Igbo nationalism and Biafra. Afrikanistik Aegyptologie Online. Retrieved from https://www.afrikanistik-aegyptologie-online.de/archiv/2011/3042.

32. Horowitz, D. L. (1985). Ethnic Groups in Conflict. Berkeley.

33. Ibenegbu, G. (2017, March 20). Geopolitical zones in Nigeria and their states. Legit. Retrievedfrom https://www.legit.ng/1094595-geopolitical-zones-nigeria-states.html.

34. Johnson, I., \& Olaniyan, A. (2017). The politics of renewed quest for a Biafra Republic in Nigeria. Defense \& Security Analysis, 33(4), 320-332.

35. Joseph, R. (1978). Political parties and ideology in Nigeria. Review of African Political Economy, 5(13), 78-90.

36. Justine, I. I. C., Chinelo, A. F., \& Ogomegbulam, A. R. (2015). The application of federal character principle and its implication on service delivery in Nigerian federal civil service. International Journal of Human Resource Studies, 5(3), 1-22.

37. Lijphart, A. (1969). Consociational democracy. World politics, 21(2), 207-225.

38. Lijphart, A. (1977). Democracy in plural societies: A comparative exploration. Yale University Press.

39. Lijphart, A. (1984). Democracies: Patterns of majoritarian and consensus government in twenty-one countries. Yale University Press.

40. Lijphart, A. (1985). Power-sharing in South Africa. Institute of International Studies, University of California.

41. Lijphart, A. (2002). The wave of power-sharing democracy. In A. Reynolds (Ed.), The architecture of democracy: Constitutional design, conflict management, and democracy (pp. 37-54). Oxford University Press.

42. Lijphart, A. (2004). Constitutional design for divided societies. Journal of democracy, 15(2), 96-109.

43. Lijphart, A. (2007). Thinking about democracy: Power sharing and majority rule in theory and practice. Routledge.

44. Loizides, N. (2016). Designing peace: Cyprus and institutional innovations in divided societies. University of Pennsylvania Press.

45. McCulloch, A., \& McGarry, J. (2009). Seeking stability amid deep division: consociationalism and centripetalism in comparative perspective. PhD thesis defended at Queens University Kingston, Ontario. 
46. McGarry, J., \& Loizides, N. (2015). Power-sharing in a re-united Cyprus: Centripetal coalitions vs. proportional sequential coalitions. International Journal of Constitutional Law, 13(4), 847-872.

47. Medina L., \& Loizides, N. (2013, July 11). Making peace in Colombia: Is a Northern Irish style power-sharing possible?. British Academics for a Colombia Under Peace. Retrieved from https://bacupblog.wordpress.com/2013/07/11/making-peace-in-colombia-isa-northern-irish-style-power-sharing-possible/.

48. Mehler, A., \& Degenhardt, C. (2008). Not always in the people's interest: Power-sharing arrangements in African peace agreements. GIGA Working Papers No 83. GIGA.

49. Moestrup, S. (2007). Semi-presidentialism in young democracies: Help or hindrance?. In R. Elgie and S. Moestrup (Eds.), Semi-presidentialism outside Europe. A comparative study (pp. 42-67). Routledge.

50. Moti, U. G. (2012). Power sharing, allocation of patronage and political stability in Nigeria. International Journal of Social Sciences and Humanities Review, 3(1), 38-49.

51. Njoku, R. C. (1999). Consociationalism: Its relevance for Nigeria. Nationalism and Ethnic Politics, 5(2), 1-35.

52. Nordlinger, E. A. (1972). Conflict regulation in divided societies (No. 29). Centre for International Affairs, Harvard University.

53. Nwonwu, F., \& Kotze, D. (2008). African political elites. African Books Collective.

54. Nwozor, A. (2014). Power rotation, ethnic politics and the challenges of democratization in contemporary Nigeria. African Study Monographs, 35(1), 1-18.

55. O'Leary, B. (2003). Consociation: Refining the theory and a defence. International Journal of Diversity in Organisations, Communities and Nations, 3, 693-755.

56. Okeke, C. E. (2019). Implementation and enforcement of the federal character principle in Nigeria. Nnamdi Azikiwe University Journal of International Law and Jurisprudence, 10(2), 174-185.

57. Orji, N. (2008). Power-sharing. The element of continuity in Nigerian politics. PhD thesis defended at the Department of Political Science, Central European University, Budapest.

58. Pasarín, A. M. F. (2011). The reform of the Council Presidency: Paving the way for a new synergy with the European Commission?. Politique Européenne, 3, 29-54.

59. Rees, A. A. (2007). Why consociationalism has not united Iraq. BA thesis defended at the Department of Political Science, Clark Honors College, University of Oregon.

60. Reilly, B. (2001). Democracy in divided societies: Electoral engineering for conflict management. Cambridge University Press.

61. Reynolds, A., Reilly, B., \& Ellis, A. (2008). Electoral system design: The new international IDEA handbook. International Institute for Democracy and Electoral Assistance.

62. Rustad, S. A. (2008). Between war and peace: 50 years of power-sharing in Nigeria. Centre for the Study of Civil War (CSCW).

63. Schneckener, U. (2002). Making power-sharing work: Lessons from successes and failures in ethnic conflict regulation. Journal of Peace Research, 39(2), 203-228. 
64. Sisk, T. D. (1996). Power sharing and international mediation in ethnic conflicts. US Institute of Peace Press.

65. Skach, C. (2011). Borrowing constitutional designs: Constitutional law in Weimar Germany and the French fifth republic. Princeton University Press.

66. Steiner, J. (1981). The Consociational Theory and beyond. Comparative Politics, 13(3), 339-354

67. Suberu, R. T., \& Diamond L. (2002). Institutional design, ethnic conflict. In A. Reynolds (Ed.), The architecture of democracy: Constitutional design, conflict management, and democracy (pp. 400-423). Oxford University Press.

68. Ukiwo, U. (2003). Politics, ethno-religious conflicts, and democratic consolidation in Nigeria. The Journal of Modern African Studies, 41(1), 115-138.

69. Worldometre (2020, April 27). Nigeria population. Retrieved from https://www. worldometers.info/world-population/nigeria-population/. 